\title{
Comparison of Finite Element Models for Particle Boards with Homogenous and Three-Layer Structure
}

\section{Usporedba simulacijskih modela za ploče iverice homogene i troslojne strukturne građe}

\author{
Original scientific paper • Izvorni znanstveni rad \\ Received-prispjelo: 28. 9. 2017. \\ Accepted-prihvaćeno: 27. 11. 2018. \\ UDK: $630 * 812.71 ; 630 * 861.232$ \\ doi:10.5552/drind.2018.1764
}

\begin{abstract}
This paper shows the results of finite element (FE) models of three-layer particle boards. Two particle board FE models were made with differently defined structures. In the first model, the structure of commercial three-layer particle board is defined as single-layer with isotropic $(P B-1 L)$ properties, while in the second model, it is defined as three-layer with orthotropic properties (PB-3L). The results of FE models were compared with values obtained by testing the commercial particle board. Dimensions of FE models and applied loads were prepared according to bending strength testing mode defined according to EN 310:1993. Model comparison is based on comparison of sample deflection and von Mises stress in the middle of the sample. The analysis was done only in linear elastic region. The obtained results show that models with homogenous material (PB-1L) achieved greater agreement with measured results (deviation app. $2 \%$ ), while models with three-layer material (PB-3L) displayed deviation of app. $7 \%$. Lower agreement of results obtained for PB-3L model and measured values of commercial particle board is due to a greater number of approximations (elastic characteristics) involved in the simulation model. Despite the greater deviation, the preparation of a three-layer model would be more acceptable for the analysis of strain distribution across the cross-section of the particle board.
\end{abstract}

Key words: particle board, structure, finite element (FE) model, bending properties

\begin{abstract}
SAŽETAK • U radu su prikazani rezultati ispitivanja simulacijskih modela troslojne ploče iverice. Izrađena su dva simulacijska modela iverice različito definirane strukturne građe. U prvom je modelu strukturna građa komercijalne troslojne ploče iverice definirana kao jednoslojna, s izotropnim (PB-1L) svojstvima, a u drugom je modelu definirana kao troslojna ploča ortotropnih svojstava (PB-3L). Vrijednosti simulacijskih modela uspoređene su s komercijalnom pločom ivericom. Dimenzije i opterećenja simulacijskih modela izrađeni su prema načinu ispitivanja savojnog opterećenja definiranoga normom EN 310:1993. Usporedba modela temelji se na usporedbi veličine progiba te von Misesovih naprezanja na sredini dužine uzorka. Analiza je provedena samo u linearno elastičnom području. Dobiveni rezultati pokazuju da je za model homogene građe (PB-1L) zabilježena veća podudarnost s mjernim rezultatima (odstupanje je iznosilo približno $2 \%$ ), dok je za modela troslojne građe (PB-3L) odstupanje bilo nešto veće (približno $7 \%$ ). Manja podudarnost rezultata dobivenih za model PB-3L nego za mjerne rezultate komercijalne ploče posljedica je većeg broja aproksimacija pri definiranju elastičnih svojstava ploče. Unatoč većem odstupanju, izrada troslojnih modela bila bi prihvatljivija za analizu raspodjele naprezanja po poprečnom presjeku ploče iverice.
\end{abstract}

Ključne riječi: ploča iverica, strukturna građa, simulacijski model, savojna svojstva

\footnotetext{
${ }^{1}$ Authors are associate professor, assistant professor and professor at University of Zagreb, Faculty of Forestry, Department of Material Technologies, Zagreb, Croatia.

Autori su izvanredni profesor, docent i redoviti profesor Zavoda za tehnologije materijala, Šumarski fakultet Sveučilišta u Zagrebu, Zagreb, Hrvatska.
} 


\section{INTRODUCTION}

\section{UVOD}

Particle boards are most commonly made as three-layer boards, where face layers are made from wood chips with smaller dimensions (passing through sieves with openings from approx. 0.125 to $2.0 \mathrm{~mm}$ ), with core layer made from slightly larger wood chips (approx. 0.355 to $4.0 \mathrm{~mm}$ ). Using different types of wood chips, different layers are formed according to physical and mechanical properties such as density, porosity, strength, modulus of elasticity, etc. However, in standard practice, only the properties of the entire particle board are stated, regardless of the composition of its layers. Based on such expression of properties, the particle board is often viewed as a homogeneous and one-layer material, ignoring the differences in their layers, which in standard use does not represent a significant problem. On the other hand, when determining, optimizing or analysing the structure, the difference between the layers has an important role and their properties are determined by various non-destructive or destructive methods (Archanowicz et al., 2013; Kazemi Najafi et al., 2005; Standfest et al., 2009; Standfest et al., 2010). Wong et al., (1999) gave a detailed analysis and comparison of the properties of particle boards with homogeneous distribution of profile density and classical U-distribution of profile density. They have concluded that commercial boards have better properties than homogeneous boards, because of their U-distributions. In further study, the effect of profile density on particle board properties was analysed by means of the finite element method (FEM) using a 2D finite element (FE) model (Wong et al., 2003). A FE model was created, based on which particle board properties can be predicted. However, in order to carry out further research, that is to make a more realistic 3D particle board analysis, it is necessary to determine all nine elastic characteristics on the assumption that the particle board is a material with orthotropic properties. This is shown in the papers (Wilczyński and Kociszewski, 2011, 2012), where all nine elastic characteristics were experimentally determined, their values being based on commercial type P4 particle boards. All nine elastic characteristics are specifically determined for face and core layers. The elastic characteristics for the whole particle board were experimentally determined for type P2 board (Archanowicz et al., 2013), where particular characteristics from the literature were used. The data obtained from the conducted researches are very useful for the development of 3D FE models, but the problem arises because the standard division (according to EN 312:2010) classifies the particle boards in seven different classes of use (P1 to P7) and eight to ten thickness classes (as depending on class of use). Experimental determination of elastic characteristics for all classes of use and all thickness classes is a very demanding job seen either from a technical or economic aspect. However, to make the results of previous researches appropriate for the analysis of other particle boards, it would be necessary to define the ratios between the individual elastic characteristics and to apply them to other types of boards. The principle of calculating individual elastic characteristics based on their mutual ratios for solid wood is reported by Kretschmann (2010). However, the question is whether the principles that apply to solid wood could be successfully applied to particle boards, especially in the analysis of particle board of different use class with different thickness. Various authors have reported that, in case of layered wood based panels, the thicknesses and properties of individual layers as well as their mutual ratios have significant influence on changes of bending properties such as deflection, force at the proportional limit and point of rupture. Additionally, it is stated that ratios of individual layers also contribute to changes of bendability and bending coefficient (Gaff et al., 2015a; Gaff et al., 2015b; Ruman et al., 2017; Svoboda et al., 2017). Such results confirm the importance of particle board analysis as multi-layered material and partially explain the influence that individual layers have on the properties of the entire board. The results obtained for layered wood based materials could be used to predict particle board tensile properties (Gašparík et al., 2017). However, the data regarding the elongation of individual particle board layer (outer or core layer) and ratios of their proportionality limits and fracture forces should not be neglected. No data that would define the elasto-plastic behaviour of particle boards have been found in available literature and this significantly complicates the prediction of their properties. Unlike particle boards, when predicting elasto-plastic behaviour of solid wood, useful data could be obtained regardless whether the tensile, compression or bending load is applied, with $16 \%$ deviation between the FE model and experimentally obtained values (Milch et al., 2016). If only the predictions of the results in elastic portion of the load-deflection curve and in the field of shear behaviour are determined, the deviations are even smaller as they are only around $7 \%$ for Norway spruce and 0.5 $\%$ for European beech (Milch et al., 2017).

Based on the above, the objectives of this paper have been set:

1. Define the elastic characteristics of $10 \mathrm{~mm}$ thick, three-layer type P2 particle board, retaining the experimentally determined elastic characteristics on the basis of the results of previous researches (Wilczyński and Kociszewski, 2012), and (Archanowicz et al., 2013)

2. Create a 3D FE model for a one-layer particle board with isotropic properties (PB-1L) and a three-layer particle board with orthotropic properties (PB-3L),

3. Compare the values of the FE models with the experimental results of the commercially available 10 $\mathrm{mm}$ thick type $\mathrm{P} 2$ particle bord (PB-com).

\section{MATERIALS AND METHODS} 2. MATERIJALI I METODE

Physical properties of commercial three-layer type $\mathrm{P} 2$ particle board used in the experiment were as follows: thickness $=10.76 \mathrm{~mm}$ (determined according to EN 325:2012), density $=0.622 \mathrm{~g} \cdot \mathrm{cm}^{-3}(\mathrm{EN} \mathrm{323:1993)}$ 


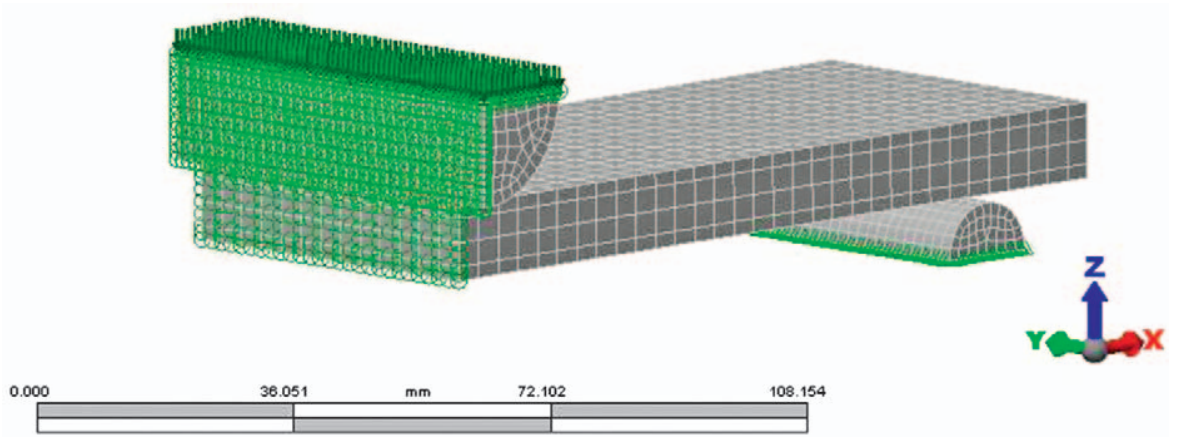

Figure 1 Finite element (FE) model for determination of bending properties according to EN 310:1993 (only half of the test sample is shown due to load symmetry)

Slika 1. Simulacijski model za određivanje savojnih svojstava prema EN 310:1993 (zbog simentričnosti opterećenja prikazano je samo pola ispitnog uzorka)

and water content $=9.02 \%($ EN 322:1993 $)$. Mechanical properties (bending strength $\left(f_{\mathrm{m}}\right)$ and modulus of elasticity (MOE)) were determined in accordance with EN 310:1993 and were as follows: $f_{\mathrm{m}}=13.2 \mathrm{~N} \cdot \mathrm{mm}^{-2}$ and $\mathrm{MOE}=2167 \mathrm{~N} \cdot \mathrm{mm}^{-2}$. In total, 12 particle board samples were experimentally tested $\left(F_{\text {mean }}=264.6 \mathrm{~N}\right.$; $F_{\text {min }}=201.6 \mathrm{~N} ; F_{\text {max }}=311.2 \mathrm{~N} ; \mathrm{COV}=13.85 \%$ ). However, in order to obtain a more realistic FE model, it was created based on actual dimensions (width $=51.0$ $\mathrm{mm}$; thickness $=10.8 \mathrm{~mm}$ ) of a single randomly chosen sample. For the same reason, the value of force used in developing the FE model was $130 \mathrm{~N}$ as obtained for individually chosen sample. Half of the actual value was used as, due to load symmetry, only half model was created.

To create FE model, software package Autodesk Simulation mechanical 2015 - Educational Institution Version was used. The 3-point bending numerical model was created as a half model with definition of symmetrical boundary conditions, see Figure 1. Brick elements with midside nodes were used to create a FE model. 3D mesh size was generated automaticaly by simulation software. The force used to make the model and load-deflection curves (Figure 2) was up to $40 \%$ of the fracture force (i.e. $0.1 F_{\max }, 0.2 F_{\max }, 0.3 F_{\max }$ and $0.4 F_{\max }$ ) so as to perform the analysis only within the limits of the linear elastic region. The thickness of each face layer was $2.0 \mathrm{~mm}$ and of the core layer $6.8 \mathrm{~mm}$. To avoid the effect of different meshing techniques on the result, both FE models had the same layout of the elements. FE models differed only in the values of elastic characteristics. The geometry of the FE model with the support and the force layout is shown in Figure 1. The model was loaded by force $(130 \mathrm{~N})$ applied vertically in negative $\mathrm{z}$ direction. Lower fixed point (support) had fixed degree of freedom (DOF), while upper support and particle bord sample had plane of symmetry to allow their movement in the $\mathrm{z}$ direction. The marks $x$-, $y$-, $z$ - indicate the direction of the boards - length, width, - thickness and the directions of the elastic characteristics $E_{\mathrm{x}}, E_{\mathrm{y}}$ and $E_{\mathrm{z}}$, respectively.

The elastic characteristics of the commercial particle board were unknown except for the global modulus of elasticity measured on the universal testing machine $\left(\mathrm{MOE}=2167 \mathrm{~N} \cdot \mathrm{mm}^{-2}\right)$.
This value of MOE was the basic value for determining other elastic characteristics. Determination of elastic characteristics was based on results of previous measurements (Wilczyński and Kociszewski, 2012) by retaining the ratio between individual elastic characteristics. The face and core layer ratios (Table 1) were adopted according to Wilczyński and Kociszewski (2012), and then the elastic characteristics values were calculated (Table 2). The principle of defining the values of the ratio between individual elastic characteristics was adapted from Kretschmann (2010), taking into consideration that these values refer to the orthotropic properties of solid wood rather than those of particle boards.

Poisson ratios were not calculated but were considered as constants. The basis for this approach is found in the fact that the difference in Poisson ratios between the face and core layers is only a few percent (Wilczyński and Kociszewski, 2012). Nonetheless, these differences may vary considerably as shown for the MDF board (Sebera et al., 2014). Although the differences in the Poisson ratios are undoubtedly present, they are relatively small if compared with the differences in the structure of the layers (the type and size of wood chips, density and porosity), where these differences are more noticeable. So a small percentage difference between Poisson ratios was also the basis for introducing an approximation (assumption) that the Poisson ratios values remain unchanged for all board types. When creating a second FE model, i.e. one-layer (homogeneous) particle board with isotropic properties, the usual value of 0.3 was used for the Poisson ratio.

In addition to determining the ratio of elastic characteristics, it was necessary to determine the MOE (in $\mathrm{x}$ - direction) for each layer. The measured MOE value $\left(2167 \mathrm{~N} \cdot \mathrm{mm}^{-2}\right)$ referred to the properties of the entire board, where MOE values for the face and core layers were not known. To determine the MOE of each layer, ratios of previous research results were used (Archanowicz et al., 2013). In the above research, MOE values are specified for the entire board $(\mathrm{MOE}=$ $2680 \mathrm{~N} \cdot \mathrm{mm}^{-2}$ ) as well as for its individual layers (face layer $\mathrm{MOE}=3050 \mathrm{~N} \cdot \mathrm{mm}^{-2}$; core layer $\mathrm{MOE}=1490$ $\mathrm{N} \cdot \mathrm{mm}^{-2}$ ). This difference in percentage values was used to determine the properties of experimentally examined commercial type 2 particle board. So, the MOE 
Table 1 Elastic constants ratios for the particle board Tablica 1. Omjeri elastičnih konstanti za ploču ivericu

\begin{tabular}{|c|c|c|}
\hline $\begin{array}{c}\text { Elastic ratio }^{\mathrm{a}} \\
\text { Elastični omjer }^{\text {Fl| }}\end{array}$ & $\begin{array}{c}\text { Face layer } \\
\text { Vanjski sloj }\end{array}$ & $\begin{array}{c}\text { Core layer } \\
\text { Središnji sloj }\end{array}$ \\
\hline$E_{\mathrm{T}} / E_{\mathrm{L}}$ & 0.862 & 0.874 \\
\hline$E_{\mathrm{R}} / E_{\mathrm{L}}$ & 0.111 & 0.126 \\
\hline$G_{\mathrm{LT}} / E_{\mathrm{L}}$ & 0.363 & 0.410 \\
\hline$G_{\mathrm{LR}} / E_{\mathrm{L}}$ & 0.077 & 0.104 \\
\hline$G_{\mathrm{TR}} / E_{\mathrm{L}}$ & 0.074 & 0.099 \\
\hline \multicolumn{2}{|c|}{ Poisson ratio $/$ Poissonov broj } \\
\hline$v_{\mathrm{xy}}$ & 0.27 & 0.28 \\
\hline$v_{\mathrm{yx}}$ & 0.23 & 0.23 \\
\hline$v_{\mathrm{xz}}$ & 0.35 & 0.34 \\
\hline$v_{\mathrm{yz}}$ & 0.35 & 0.30 \\
\hline$v_{\mathrm{zx}}$ & 0.04 & 0.04 \\
\hline$v_{\mathrm{zy}}$ & 0.05 & 0.05 \\
\hline
\end{tabular}

a Elastic ratios were adopted from Wilczyński and Kociszewski (2012) (e.g. $\left.E_{\mathrm{T}}=3.82 ; E_{\mathrm{L}}=4.43\right)$ and after that calculated (e.g. $E_{\mathrm{L}} / E_{\mathrm{T}}$ $=3.82 / 4.43=0.862) /$ elastični omjeri preuzeti su iz rada Wilczyński $i$ Kociszewski (2012) (e.g. $\left.E_{T}=3,82 ; E_{L}=4,43\right)$ i nakon toga izračunani (e.g. $\left.E_{L} / E_{T}=3,82 / 4,43=0.862\right)$;

Poissons ratios were adopted from Wilczyński and Kociszewski (2012) / Poissonovi brojevi preuzeti su iz rada Wilczyński i Kociszewski (2012.)

of the core layer is $55.6 \%$ lower than the MOE of the entire board, while the MOE of the face layer is $13.8 \%$ higher than the MOE of the entire board (Table 2).

\section{RESULTS AND DISCUSSION 3. REZULTATI I RASPRAVA}

The results of the deflection for the control particle board and the FE models are shown in Figure 2 and Table 3. From load-deflection curves made based on data obtained from 0.1 to $0.4 F_{\text {max }}$ (Figure 2), it is apparent that the values of both FE models match the values of control (commercial) particle board with high-accuracy. Table 3 clearly shows that the FE model PB-1L has fewer and almost insignificant deviations (app. $2 \%$ ) than the control particle board, while the PB-3L model has slightly larger deviations (app. $7 \%$ ), both of which are significantly lower than the obtained COV value $(13.85 \%)$. This is because PB-1L modelling used the actual (measured) value of the MOE, while the MOE of the PB-3L model was calculated. The uncertainty of the calculation values stems from the fact that the literature values of the elastic characteristics are determined on different types of particle boards of different thickness. Additional reason of larger deviation of the results for the PB$3 \mathrm{~L}$ board is the approximation of the structure in the creation of this model. Namely, the actual distribution of the profile density is carried out gradually, whereby the density of the board gradually decreases from the face layer towards the core layer. In the FE model, the transition from the face
Table 2 Elastic constants (calculation values) used in creating of FE model

Tablica 2. Elastične konstante (proračunske vrijednosti) za izradu simulacijskog modela FEM

\begin{tabular}{|c|c|c|c|}
\hline \multirow{2}{*}{$\begin{array}{l}\text { Elastic } \\
\text { ratio } \\
\text { Elastični } \\
\text { omjer }\end{array}$} & \multicolumn{2}{|c|}{$\begin{array}{l}\text { Orthotropic model } \\
\text { Ortotropni model } \\
\text { (Calculated values) } \\
\text { (proračunske vrijednosti) }\end{array}$} & \multirow{2}{*}{$\begin{array}{c}\text { Isotropic } \\
\text { model } \\
\text { Izotropni } \\
\text { model } \\
\text { Entire board } \\
\text { Cijela ploča }\end{array}$} \\
\hline & $\begin{array}{l}\text { Face layer } \\
\text { Vanjski sloj }\end{array}$ & $\begin{array}{l}\text { Core layer } \\
\text { Središnji sloj }\end{array}$ & \\
\hline$E_{\mathrm{L}}$ & 2465 & 1204 & \multirow{6}{*}{$E_{\mathrm{L}}=2167^{\mathrm{a}}$} \\
\hline$E_{\mathrm{T}}$ & 2125 & 1052 & \\
\hline$E_{\mathrm{R}}$ & 273 & 152 & \\
\hline$G_{\mathrm{LT}}$ & 895 & 493 & \\
\hline$G_{\mathrm{LR}}$ & 190 & 125 & \\
\hline$G_{\mathrm{TR}}$ & 182 & 119 & \\
\hline \multicolumn{4}{|c|}{ Poisson ratio / Poissonov broj } \\
\hline$v_{x y}$ & 0.27 & 0.28 & \multirow{6}{*}{$v_{x y}=0.3$} \\
\hline$v_{\mathrm{yx}}$ & - & - & \\
\hline$v_{x z}$ & 0.35 & 0.34 & \\
\hline$v_{\mathrm{yz}}$ & 0.35 & 0.30 & \\
\hline$v_{z x}$ & - & - & \\
\hline$v_{\mathrm{zy}}$ & - & - & \\
\hline
\end{tabular}

${ }^{a}$ Measured value / izmjerena vrijednost

to the core layer is stepwise, i.e. there is no transition area in the middle. Due to the larger share of the core layer compared to the actual particle board, a model with a slightly larger deflection (less stiff) is obtained. Although models of the profile density and density predictions of particle boards can be found in the literature (Suo and Bowyer, 1994; Zhou et al., 2011; Gamage and Setunge, 2015), it is necessary to define the correlation ratios of density and MOE to define the elastic properties of each layer.

Examining the stress values in the particle board, it is evident that there is a significant difference only in the distribution of stress. In the three-layer orthotropic mod$\mathrm{el}$, the role of face layers is more distinct as, due to their higher mechanical properties, they take more stress and thus relieve the core layer. Von Mises stress values at

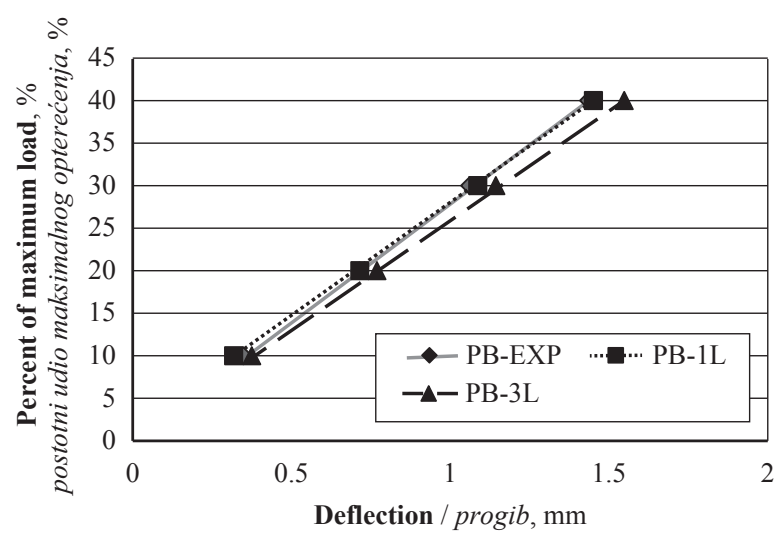

Figure 2 Load-deflection curves within the region of elastic deformation (EN 310:1993)

Slika 2. Krivulje progiba - opterećenja unutar raspona elastične deformacije (EN 310:1993) 


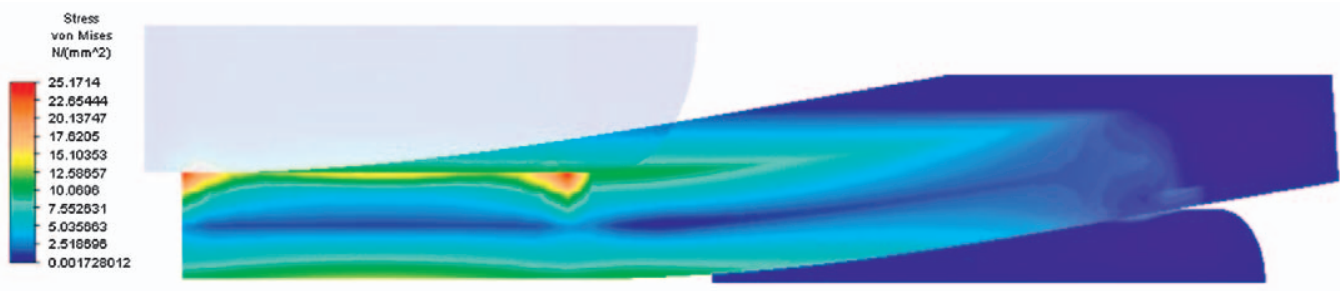

PB-1L

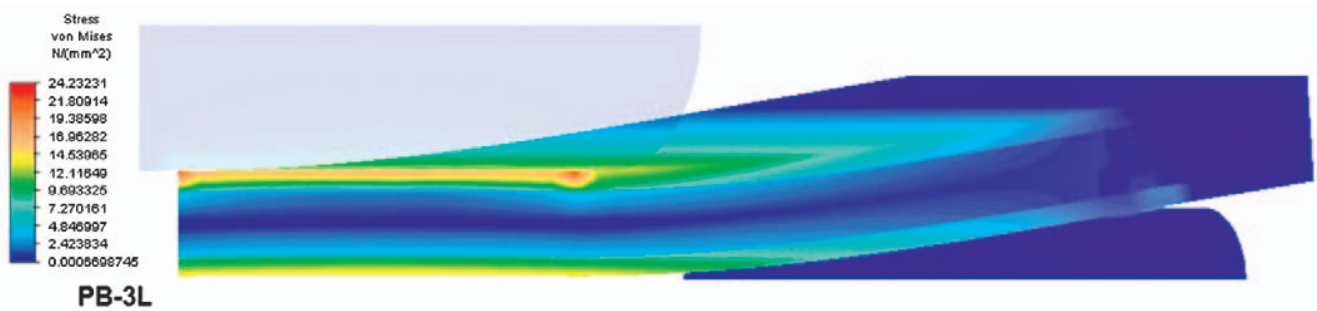

Figure 3 Values and distribution of von Mises stresses for PB-1L and PB-3L boards (Upper support surfaces are shaded for better stress display)

Slika 3. Vrijednosti i raspodjela von Misesovih naprezanja za ploče PB-1L i PB-3L (površine gornjeg oslonca osjenčane su radi boljeg prikaza naprezanja)

Table 3 Deflection values for examined particle board and FE models

Tablica 3. Vrijednosti progiba ispitivane ploče iverice i simulacijskih modela

\begin{tabular}{|c|c|c|c|}
\hline Percentage of max load & \multicolumn{3}{|c|}{ Deflection / Progib, $\mathrm{mm}$} \\
\cline { 2 - 4 } $\begin{array}{c}\text { Postotni udio maksimal- } \\
\text { nog opteré́enja \% }\end{array}$ & PB-EXP & PB-1L & PB-3L \\
\hline 10 & 0.35 & 0.32 & 0.37 \\
\hline 20 & 0.71 & 0.72 & 0.77 \\
\hline 30 & 1.06 & 1.09 & 1.14 \\
\hline 40 & 1.44 & 1.45 & 1.55 \\
\hline
\end{tabular}

$F_{\text {max }}$ are shown in Figure 3. The maximum values of the von Mises stresses are not significantly different (24.2 $\mathrm{N} \cdot \mathrm{mm}^{-2}$ for PB-3L and $25.17 \mathrm{~N} \cdot \mathrm{mm}^{-2}$ for PB-1L) and occur on the upper side of the experimental sample directly below the central support, where in actual measurement local retraction of face layer forms.

For the analysis of bending strength, stresses from the underside of the sample were observed at the middle of the length, where in reality the fracture of the test sample was formed. The control particle board (PB-EXP) had a bending strength of $\left(f_{\mathrm{m}}=13.2 \mathrm{~N} \cdot \mathrm{mm}^{-2}\right)$ as determined at $F_{\text {max. }}$ In the FE model, the values determined at $F_{\max }$ were similar to PB-1L $\left(f_{\mathrm{m}}=13.0\right.$ $\mathrm{N} \cdot \mathrm{mm}^{-2}$ ), while for the PB-3L model, it was slightly higher $\left(f_{\mathrm{m}}=14.8 \mathrm{~N} \cdot \mathrm{mm}^{-2}\right)$. Although the results of the FE model are only based on the linear analysis, it is evident that the particle board strength can be predicted with satisfactory accuracy.

Based on these results, it can be concluded that the literature data for one type of particle board can be used to predict the properties of the other type and other thickness of particle board. It is also evident that the average deviation of the simulation values from the actual values is about $7 \%$, which is acceptable considering a small number of known (measured) elastic characteristics. However, the variability of experimental results $(\mathrm{COV}=13.85 \%)$ and the fact that the FE model was only based on literary values (except the global MOE) must be taken in consideration.

\section{CONCLUSIONS \\ 4. ZAKLJUČAK}

Based on the results of the FE model and the standardized method of determining the bending properties of the particle board, it can be concluded that modelling can achieve satisfactory results in solving real (practical) problems as to whether the particle board is defined as a one-layer board with isotropic properties or three-layer board with orthotropic properties. More precise results were achieved using a onelayer isotropic model (app. $2 \%$ deviation), while a slightly higher deviation from the control sample was observed in the three-layer orthotropic model (app. 7 $\%$ ). The reason for a higher deviation in the three-layer orthotropic model is the introduction of a greater number of approximations of particular properties. Based on the MOE value of the entire board, it is not possible to precisely determine the MOE values of individual layers (face and core), the transition layer properties between these two layers are not yet defined, and a more significant approximation of Poisson ratios is also performed. However, in spite of the greater number of approximations, the deviation of the obtained results from the realistic results is about $7 \%$, which can be considered acceptable. However, for a more realistic stress distribution analysis, the three-layer (or multilayer) model should be a priority because the inhomogeneity of the three-layer particle board is very noticeable both from the aspect of mechanical and physical properties.

It can also be concluded that by retaining the elasticity properties ratio of the type P4 particle board (18 $\mathrm{mm}$ ) and using the same Poisson ratios, it is possi- 
ble to relatively successfully predict the properties of particle board from different class of use (P2) and of different thickness $(10 \mathrm{~mm})$.

\section{REFERENCES}

\section{LITERATURA}

1. Archanowicz, E.; Kowaluk, G.; Niedziński, W.; Beer, P., 2013: Properties of particleboards made of biocomponents from fibrous chips for FEM modeling. BioResources, 8 (4): 6220-6230.

http://doi.org/10.15376/biores.8.4.6220-6230.

2. Gaff, M.; Gašparík, M.; Borůvka, V.; Haviarová, E., 2015a: Stress simulation in layered wood-based materials under mechanical loading. Materials and Design, 87: 1065-1071.

http://dx.doi.org/10.1016/j.matdes.2015.08.128.

3. Gaff, M.; Gašparík, M.; Borůvka, V.; Babiak, M., 2015b: Simulating stresses associated with the bending of wood using a finite element method. BioResources, 10 (2): 2009-2019.

http://doi.org/10.15376/biores.10.2.2009-2019.

4. Gamage, N.; Setunge, S., 2015: Modelling of vertical density profile of particleboard, manufactured from hardwood sawmill residue. Wood Material Science \& Engineering, 10 (2): 157-167. http://dx.doi.org/10.1080/17480272.2014.923043.

5. Gašparík, M.; Gaff, M.; Babiak, M., 2017: Tension stress simulations of layered wood using a finite element method. Wood research, 62 (4): 517-528.

6. Kazemi Najafi, S.; Bucur, V.; Ebrahimi, G., 2005: Elastic constants of particleboard with ultrasonic technique. Materials Letters, 59: 2039-2042.

http://dx.doi.org/ 10.1016/j.matlet.2005.02.013.

7. Kretschmann, D. E., 2010: Mechanical properties of wood. U: R. J. Ross (ed.): Wood handbook - Wood as an engineering material. Madison, Wisconsin, Forest Products Society, pp. 86-88.

8. Milch, J.; Tippner, J.; Sebera, V.; Brabec, M., 2016: Determination of the elasto-plastic material characteristics of Norway spruce and European beech wood by experimental and numerical analyses. Holzforschung, 70 (11): 1081-1092. https://doi.org/10.1515/hf-2015-0267.

9. Milch, J.; Sebera, V.; Brabec, M.; Tippner, J., 2017: Verification of the elastic material characteristics of Norway spruce and European beech in the field of shear behaviour by means of digital image correlation (DIC) for finite element analysis (FEA). Holzforschung, 71 (5): 405414. https://doi.org/10.1515/hf-2016-0170.

10. Ruman, D.; Záborský, V.; Svoboda, T.; Kašičková, V.; Rodrová, V., 2017: Identifying the characteristics of laminated wood based on the values of deflection measured during its bending. BioResources, 12 (2): 2592-2608. http://doi.org/10.15376/biores.12.2.4146-4165.

11. Sebera, V.; Tippner, J.; Šimek, M.; Šrajer, J.; Děcký, D.; Klímová, H., 2014: Poisson's ratio of the MDF in respect to vertical density profile. European Journal of Wood and Wood Products, 72 (3): 407-410. http://dx.doi.org/10.1007/s00107-014-0780-1.

12. Standfest, G.; Petutschnigg, A.; Dunky, M.; Zimmer, B., 2009: Rohdichtebestimmung von Holzwerkstoffen mit- tels Computertomographie. European Journal of Wood and Wood Products, 67 (1): 83-87. http://dx.doi.org/10.1007/s00107-008-0289-6.

13. Standfest, G.; Kranzer, S.; Salaberger, D.; Plank, B.; Petutschnigg, A.; Dunky, M., 2010: 3D microstructure characterization of wood based panels. U: Teischinger, A.; Barbu, M. C.; Dunky, M.; Harper, D.; Jungmeier, G.; Militz, H.; Musso, M.; Petutschnigg, A.; Pizzi, A.; Wieland, S.; Young, T. M. (eds.): Processing Technologies for forest and biobased products industries. Kuchl, Austria, Salzburg University of Applied Sciences, pp. 96-101.

14. Suo, S.; Bowyer, J. L., 1994: Simulation modelling of particleboard density profile. Wood and Fiber Science, 26(3): 397-411.

15. Svoboda, T.; Gaffová, Z.; Rajnoha, R.; Šatanová, A.; Kminiak, R., 2017: Bending forces at the proportionality limit and the maximum - technological innovations for better performance in wood processing companies. BioResources, 12 (2): 4146-4165. http://doi.org/10.15376/biores.12.2.4146-4165.

16. Wilczyński, A.; Kociszewski, M., 2011: Determination of elastic constants of particleboard layers by compressing glued layer specimens. Wood Research, 56 (1): 7791.

17. Wilczyński, A.; Kociszewski, M., 2012: Elastic properties of the layers of three-layer particleboards. European Journal of Wood and Wood Products, 70 (1-3): 357-359. http://dx.doi.org/10.1007/s00107-010-0497-8.

18. Wong, E. D.; Yang, P.; Zhang, M.; Wang, Q.; Nakao, T.; Li, K. F.; Kawai, S., 2003: Analysis of the effects of density profile on the bending properties of particleboard using finite element method (FEM). Holz als Roh-und Werkstoff, 61 (1): 66-72. http://dx.doi.org/10.1007/s00107-002-0350-9.

19. Zhou, C.; Dai, C.; Smith, G. D., 2011: Modeling vertical density profile formation for strand-based wood composites during hot pressing: Part 1. Model development. Composites Part B: Engineering, 42(6): 1350-1356. http://doi.org/10.1016/j.compositesb.2011.05.036.

20. *** EN 310, 1993: Wood based panels - Determination of modulus of elasticity in bending and of bending strength.

21. *** EN 312, 2010: Particleboards - Specifications.

22. *** EN 322, 1993: Wood based panels - Determination of moisture content.

23. *** EN 323, 1993: Wood-based panels - Determination of density.

24. *** EN 325, 2012: Wood based panels - Determination of dimension of test pieces.

\section{Corresponding address:}

Assist. prof. NIKOLA ŠPANIĆ, Ph.D.

Department of Material Technologies

University of Zagreb, Faculty of Forestry

Svetošimunska 25, p.o. box 422

10002 Zagreb, CROATIA

e-mail: nspanic@sumfak.hr 